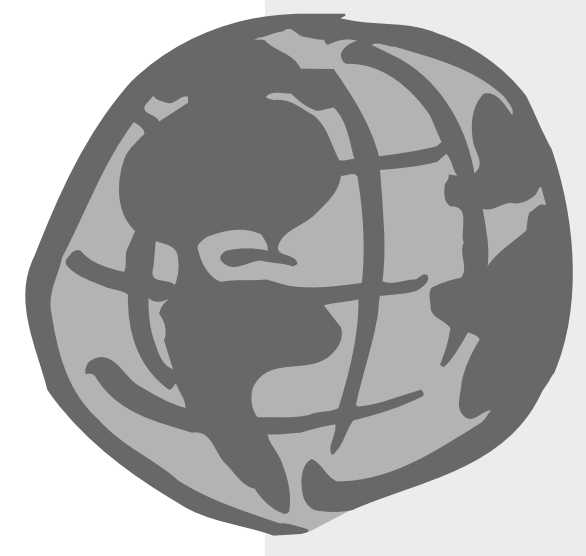

\title{
TECHNOLOGY COOPERATION AGREEMENT PILOT PROJECT
}

\section{Development-Friendly Greenhouse Gas Reduction}

\section{STATUS REPORT}

October 1998

Prepared by the National Renewable Energy Laboratory

For

U.S. Agency for International Development

U.S. Environmental Protection Agency

U.S. Department of Energy

Much of this report is excerpted from the Technology Cooperation Framework documents written by the TCAPP teams in Brazil, China, Kazakhstan, Mexico and the Philippines

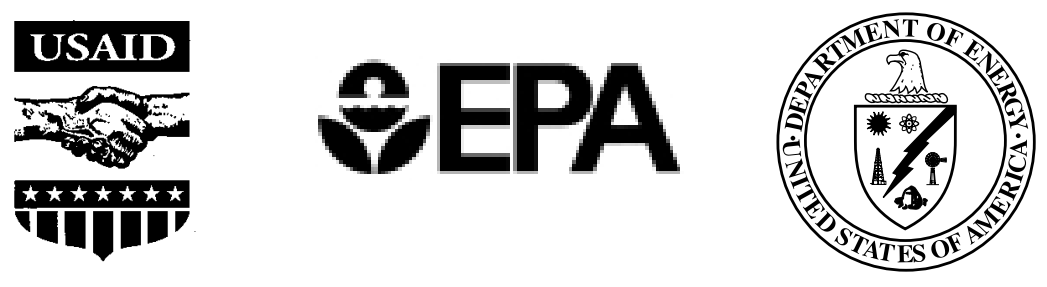




\section{NOTICE}

This report was prepared as an account of work sponsored by an agency of the United States government. Neither the United States government nor any agency thereof, nor any of their employees, makes any warranty, express or implied, or assumes any legal liability or responsibility for the accuracy, completeness, or usefulness of any information, apparatus, product, or process disclosed, or represents that its use would not infringe privately owned rights. Reference herein to any specific commercial product, process, or service by trade name, trademark, manufacturer, or otherwise does not necessarily constitute or imply its endorsement, recommendation, or favoring by the United States government or any agency thereof. The views and opinions of authors expressed herein do not necessarily state or reflect those of the United States government or any agency thereof.

Available to DOE and DOE contractors from:

Office of Scientific and Technical Information (OSTI)

P.O. Box 62

Oak Ridge, TN 37831

Prices available by calling 423-576-8401

Available to the public from:

National Technical Information Service (NTIS)

U.S. Department of Commerce

5285 Port Royal Road

Springfield, VA 22161

703-605-6000 or 800-553-6847

or

DOE Information Bridge

http://www.doe.gov/bridge/home.html

Printed on paper containing at least $50 \%$ wastepaper, including $20 \%$ postconsumer waste 


\title{
Introduction
}

The U.S. Government initiated the Technology Cooperation Agreement Pilot Project (TCAPP) in August 1997 in recognition of the need to establish a mechanism for implementing Article 4.5 of the Framework Convention on Climate Change.

\begin{abstract}
"The developed country partners...shall take all practicable steps to promote, facilitate and finance, as appropriate, the transfer of, or access to, environmentally sound technologies and know-how to other Parties, particularly developing country Parties, to enable them to implement the provisions of the Convention."
\end{abstract}

TCAPP builds support for implementing clean energy technologies by facilitating collaboration among the participating countries, the United States and other OECD countries, international donors, and the private sector. The governments of Brazil, China, Kazakhstan, Mexico and the Philippines are currently participating and helping to shape this initiative. International donors and the private sector have also been actively engaged in the design and implementation of this pilot program.

The TCAPP design begins with an emphasis on a country-driven process to identify technology needs. It's a voluntary partnership - countries participate because they can direct the program towards activities that meet their own sustainable development priorities while accelerating the implementation of clean energy technologies. Private sector participation ensures that activities are aimed at creating a viable marketplace for these technologies. This is also an attractive feature to donors, who are trying to leverage their resources with private investment. Donors have also expressed interest in TCAPP as a framework that can help them coordinate their efforts on a common set of country priorities. TCAPP has gained recognition as a program that could be a potential model for technology cooperation under the Framework Convention on Climate Change (FCCC).

This paper provides an overview of TCAPP, including the methodology, the results to date, and proposed future activities. It includes a detailed description of the technology cooperation frameworks completed by each country, the process that produced them and the plans for how TCAPP will help to implement the directions articulated by the country teams.

Some of the most significant accomplishments of TCAPP thus far include:

- Intergovernmental teams in Brazil, China, Kazakhstan, Mexico, and the Philippines have prepared climate change technology cooperation frameworks. These frameworks define priority clean energy technologies for meeting development goals and reducing green house gas (GHG) emissions and actions necessary to accelerate investment in these technologies. Senior government officials from these countries have endorsed this work, with active participation of key in-country stakeholders and project implementers.

- TCAPP has established a network of international energy companies and investment organizations interested in participating in the TCAPP process to help mobilize private investment in the country priorities. This network, already numbering over 100 companies and growing, is helping identify the most promising clean energy investment opportunities in 
the countries and the critical actions that in-country agencies and donor organizations can take to remove market barriers and facilitate private investment.

- TCAPP has actively engaged key OECD and multilateral donor organizations in program design over the past year. More than 30 representatives from bilateral and multilateral donor organizations participated in a recent workshop in Washington on October 9th, 1998 with the country teams. These donor organizations have highlighted the value of TCAPP as a mechanism for establishing a common set of country climate change technology priorities, for engaging the private sector in actions to attract clean energy investment, and for coordinating donor programs to address country technology and sustainable development needs.

\section{The TCAPP Approach}

TCAPP was initiated in August 1997 in recognition of the need to establish a mechanism for implementing Article 4.5 of the Framework Convention on Climate Change. It is currently supported by three U.S. agencies, the Agency for International Development, the Environmental Protection Agency and the Department of Energy.

The National Renewable Energy Laboratory (NREL) leads the implementation of TCAPP for the U.S. Government. NREL, together with Sandia National Laboratory, the Business Council for Sustainable Energy (BCSE) and numerous other cooperators, assist country teams in developing and implementing technology cooperation frameworks and in engaging private sector organizations and international donor agencies. Financial support is also provided to the country teams for their work.

\section{Goals}

- Foster private investment in energy technologies that reduce GHG emissions and produce economic benefits for the country.

- Engage in-country and international donor support for actions to build sustainable markets for clean energy technologies.

- Establish technology cooperation agreements as an organizing structure for coupling incountry, donor, and private-sector climate change mitigation actions.

\section{Key Principles}

A number of key principles have helped shaped the design of TCAPP.

- The selection of technology priorities must be country driven and reflect input from all key stakeholders in the country

- Technology priorities must contribute both to near-term sustainable development goals and GHG reduction

- Country and donor efforts will only be effective if they are successful at attracting private investment

- Coordination of country activities and the actions of multiple donors will be more effective than unilateral donor actions. 
1. TCAPP is country-driven. In-country teams led by senior government officials and with active participation of all key government, private sector, and non-government stakeholders establish the technology priorities. TCAPP provides small amounts of funding for in-country coordination and technical guidance and review, but is only a minor source of financial support. In-country organizations participate because they are motivated to pursue the priorities they set and they believe that TCAPP offers them a chance to realize these priorities.

2. Country teams select priority technologies based on the contribution of these technologies to national development goals and their potential for greenhouse gas reduction. Each country team has established its own set of criteria for selecting priorities. These criteria generally include consideration of social and economic development goals, local environmental benefits, potential attractiveness of the technology to private investors, and potential contribution to greenhouse gas reduction. Countries build on their previous work in programs such as the Global Environment Facility Enabling Activities and the U.S. Country Studies Program and Support for National Action Plans as well as their own national processes. By employing priorities that are already well established, country teams can avoid using time and resources needlessly reassessing direction.

3. TCAPP is market oriented, focusing on opportunities to attract private investment in country technology needs. TCAPP encourages the country teams to solicit feedback from in-country businesses and investors on the best opportunities for clean energy investment and most critical country and donor actions to support this investment. Through the Business Council for Sustainable Energy, TCAPP has also established and is continuing to expand a network of international energy companies and investment organizations to provide similar feedback on investment opportunities and country and donor actions to promote investment. These actions include directly facilitating private investment and removal of legal, policy, or institutional barriers to attracting such investment.

4. TCAPP is designed to encourage actions by the host country while it promotes active participation and collaboration between the international donor community in response to the country technology cooperation needs. The U.S. Government has worked with the OECD, IEA, GEF, World Bank, UNEP, UNDP, and various other OECD countries and other multilateral donor organizations to design TCAPP so it will be a useful mechanism for donors to respond in a coordinated way to country technology needs. TCAPP aims to attract donor support for both the work of the country teams in designing actions to attract clean energy investment and for implementation of actions to address market barriers and directly facilitate investment deals. For instance, TCAPP is working with United Nations Environment Program and the World Business Council for Sustainable Development on a proposal to implement in-country business capacity building activities in response to the country needs in this area.

\section{TCAPP Methodology}

TCAPP has two basic phases of activities. In the first phase, which the five participating countries have carried out over the past year, TCAPP country teams have developed technology cooperation frameworks that define their technology cooperation priorities and actions to attract investment in these technologies. In the second phase, TCAPP assists the country teams in attracting in-country, donor, and private investment support for implementing these actions, 
which address market barriers and promote direct private investment. All of these activities require close collaboration between in-country government agencies, businesses, and NGOs, the international donor community, and international businesses and investors. This process is depicted in the figure below.

\section{The TCAPP Process}

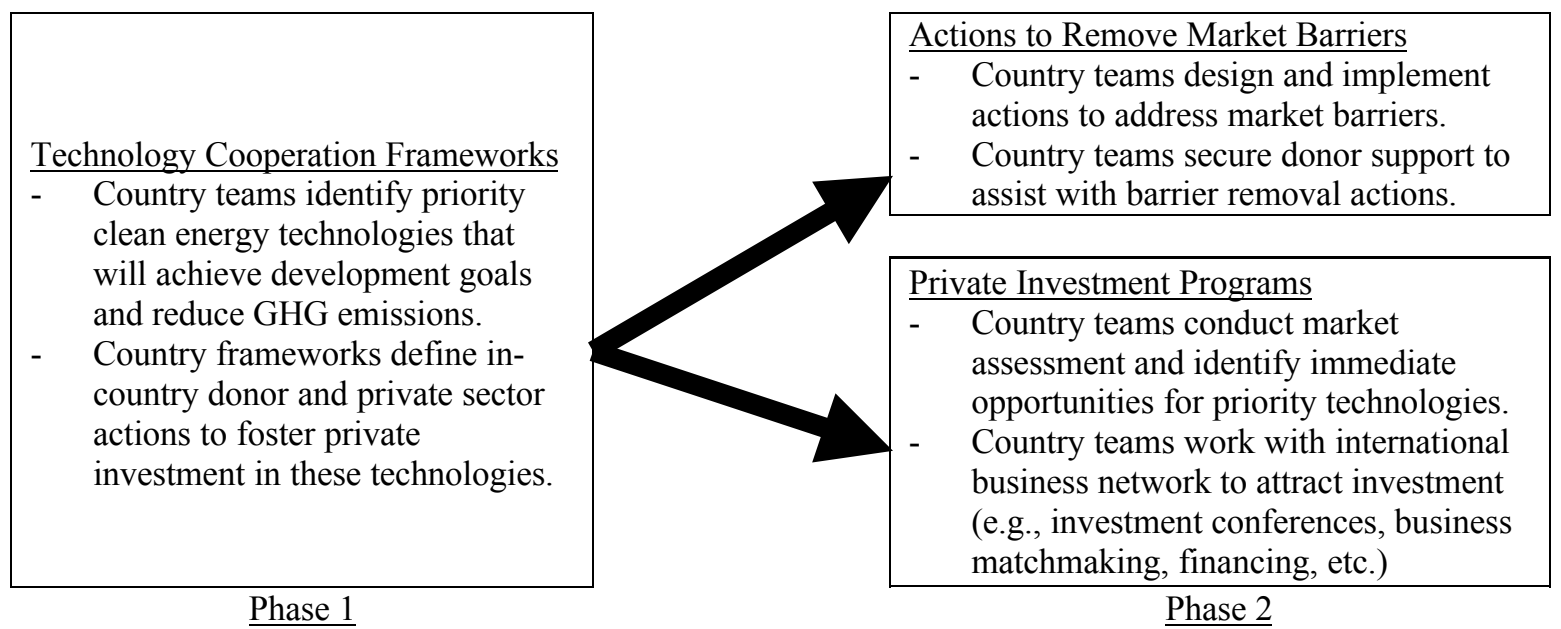

\section{Major Program-Wide Activities in TCAPP's First Year}

Activities were carried out in four major areas in the first year of TCAPP: 1) program design; 2) development of country technology cooperation frameworks; 3 ) private sector participation; and 4) international donor participation. Each area is described below.

\section{Program Design}

The National Renewable Energy Laboratory and the U.S. Government agencies supporting TCAPP worked closely with developing and transition country officials, donor representatives, and international energy businesses and associations to develop an effective design for TCAPP. This work on program designed occurred through individual consultations with these different groups, as well as a workshop held at NREL in November, 1997.

NREL initiated work with Brazil, Indonesia, India, Kazakhstan, Mexico, and the Philippines prior to this workshop. Officials from these countries presented preliminary frameworks to international donor and private sector representatives at this workshop. This provided a foundation for discussions between the country and donor officials and private sector representatives on how the program design could be improved. A total of 40 country, donor, and private sector representatives participated in this workshop.

The workshop was a unique opportunity for country team representatives and the international donor and private sector communities to share ideas about attracting private investment. The attendees expressed strong support for the TCAPP concept. The participants commented on the need for a rigorous and consultative process of selecting country technology priorities, the value of focusing on opportunities to attract private investment and thus the need for active business 
involvement in the TCAPP process, and the key role of TCAPP in facilitating broad donor participation and coordination.

\section{Preparation of Technology Cooperation Frameworks}

The Technology Cooperation Framework is the foundation for TCAPP. It documents the process the country used to select priorities, the priority technologies resulting from this process, and the reasons why these priorities were selected. The frameworks describe the barriers to private investment for these technologies and identify opportunities for coupling actions by domestic agencies, international donors, and private sector investors to achieve sustained investment in the technologies. The frameworks are designed to contain the information most crucial to attract interest from international donors and the private sector.

The five countries have completed several steps in their effort to produce Technology Cooperation Frameworks.

1. In-country teams were established to guide the preparation of the technology cooperation frameworks. Teams were usually led by the energy ministry, since this is often the agency most responsible for implementation in the energy sector. Other ministries and stakeholders also participated in the teams. TCAPP has been fortunate to have had motivated and influential individuals act as the lead for the team. In Brazil, for example, the Director of Energy Development at the Ministry of Mines and Energy, who oversees the government's activities in energy efficiency and renewable energy, is the team lead. In most cases, the team lead is assisted by others who have influence and are interested in the goals of TCAPP. In the Philippines, the team lead from the Department of Energy has been receiving support from the Presidential Assistant on Poverty Alleviation.

2. In-country teams developed a short list of possible technology priorities. Countries were encouraged to utilize established priorities if these priorities were strongly supported. Most countries have undertaken priority setting exercises before, either for the purpose of energy planning, for economic development, or for climate change assessments. This approach has already demonstrated that enabling developing countries to consider the full range of options and allowing them to apply the criteria that is most meaningful to them has two important benefits. First, countries are more serious about pursuing their own priorities. And second, because a country is likely to already be making efforts to pursue these priorities, there are resources and capacity to build on.

For each priority, teams identified key market barriers and identified possible actions that can be taken in-country or by donor agencies to eliminate the barrier. Barriers can range from complex legal issues having to do with ownership, enforcement of contracts, or measurement of performance, to simpler problems such as a lack of awareness.

3. Teams refined the list of priorities, proposed in-country, donor, and private sector actions and prepared a comprehensive technology cooperation framework. This refinement occurs through consultations with technical experts, private companies, and international donors. More important were the in-country consultations with experts, stakeholders and other government agencies. When conducted correctly, in-country consultations help attract the support of the parties who will be involved in the decision of whether the project goes ahead and the support of those who will implement. The validation process in Brazil involved conducting a series of meetings to address the different priority areas. The meeting on direct use of fossil fuels and transportation required a different group of people than the meeting on 
rural renewable energy technologies, for example. The review process for the technology cooperation framework included senior government officials once a complete draft document was prepared.

\section{Private Sector Involvement}

The primary goal of TCAPP is to foster sustainable commercial markets in clean energy technologies. This goal is reinforced by having the private sector involved in each step of the TCAPP process. Representatives of the different types of energy efficiency and renewable energy businesses attended the workshop in Golden, Colorado, in November of 1997. Their presence helped the country representatives and the other attendees maintain a market focus.

In March, BCSE , an international association of energy efficiency and renewable energy businesses, joined TCAPP to facilitate a high degree of private sector engagement in TCAPP. BCSE's activities include identifying companies interested in TCAPP countries and their priorities, soliciting feedback from the businesses on the barriers and the proposed activities reported by the TCAPP countries, and attracting the interest of these companies in making investments of their resources in the TCAPP countries.

BCSE has now established a network of over 100 companies and investment organizations interested in participating in TCAPP to help mobilize private investment in the country priorities. In September, representatives from 24 companies and four trade associations attended a meeting on TCAPP hosted by USAID. The administrator of USAID, Brian Atwood, welcomed the group and explained the interest AID has in collaborating with the private sector as they pursue their 5year, $\$ 1$ billion portfolio of climate change related activities. Many companies expressed interest in meeting with the TCAPP country teams, which were scheduled to meet in Washington just 2 weeks later. As a result, time was set aside during this scheduled visit of the country teams to allow for one-on-one meetings with company representatives.

\section{International Donor Agency Participation}

A key TCAPP goal is to achieve active engagement of international donors in supporting actions by countries that will build sustainable markets for their clean energy technology priorities.

Donor involvement in the program began in the design stage, when discussions with donors in the first half of 1997 inspired the birth of TCAPP. Donors have continued to be involved in a number of ways. TCAPP has held individual consultations with headquarters and field donor representatives. Several international donor agencies sent representatives to the November 1997 TCAPP workshop in Golden, Colorado. International donors also attended the TCAPP side event at COP3 in Kyoto, when representatives from the Brazil and Philippines TCAPP teams made short presentations along with USAID, NREL, and the International Energy Agency.

Through these interactions, donor organizations identified three attributes of TCAPP of particular interest

- TCAPP provides a common set of country clean energy investment priorities reflecting input from key agencies and stakeholders in the country that can help focus donor activities.

- TCAPP provides donor organization with a valuable mechanism for participation of private sector businesses and investors in clean energy initiatives.

- TCAPP can serve as a mechanism to help focus donor activities on country clean energy and climate change technology needs. 
In an effort to bring TCAPP countries and international donors together in the most productive way possible, NREL organized a meeting in Washington on October 9, 1998, in which TCAPP countries could present their Technology Cooperation Frameworks to international donors. The five TCAPP countries each sent one or two senior representatives of their country teams. More than 30 representatives of international donor agencies attended this meeting. A number of other international donor representatives who did not attend sent in requests for more information on TCAPP.

The October 9th meeting enabled each of the TCAPP countries to present a summary of its Technology Cooperation Frameworks. Each country also met individually with donor representatives to discuss opportunities for collaboration in responding to the country technology needs. The meeting participants identified six next steps that could be pursued to broaden donor participation in TCAPP and further enhance the value of TCAPP to the donor community.

- The country teams should work with donor organizations to better define how their specific needs for support relate to and build on current donor programs.

- TCAPP should explore opportunities to become more of a multilateral program and to secure support from other donors (beyond the United States) for the overall work of the country teams under TCAPP, including designing actions to address market barriers and developing investment programs.

- The U.S. institutions supporting TCAPP should pursue joint development of projects with the international donor organizations where there is a match of donor interests and country needs identified in the frameworks.

- TCAPP should continue its efforts to promote donor coordination and should work with the donor community to develop appropriate mechanisms for ongoing donor coordination in responding to climate change technology cooperation needs.

- The experiences of TCAPP should be shared at COP-4 to promote further consideration of TCAPP as one model for implementing Article 4.5 of the FCCC.

- TCAPP should continue its efforts to expand international business and finance organization participation in efforts to foster private investment in the priority technologies.

\section{Overview of the Technology Cooperation Frameworks}

\section{BRAZIL}

Brazil's TCAPP effort began with a scoping meeting in September 1997, in which energy experts from the Ministry of Mines and Energy and the Research Center for Electrical Energy (CEPEL) agreed to participate in the program and developed an initial set of technology priorities. CEPEL took the lead in preparing a Preliminary Technology Cooperation Framework, which two members of the team presented at the November 1997 workshop in Golden, Colorado. The interchange at the workshop helped the Brazil team to refine the priorities.

One member of the Brazil team attended COP3 in Kyoto and presented the Brazil priorities at a TCAPP side event, which attracted attendees from quite a number of delegations, NGOs and international donors.

A series of TCAPP planning meetings were held in Rio de Janeiro and Brasilia in July 1998. The TCAPP meetings resulted in the selection and confirmation of five priorities, which are listed 
below. One priority, electrical energy efficiency, was not discussed in detail, because a large conference was being planned for October 1998 which was being designed to select priorities for PROCEL, the large electrical energy efficiency program. The PROCEL representative at the TCAPP planning meeting agreed to revisit this priority area after the October conference.

TCAPP employed a consultant from the Foundation for Sustainable Development (FBDS) to assist in setting up the planning meetings and to assist in drafting the Technology Cooperation Framework. Brazil completed the draft Technology Cooperation Framework in September, 1998.

\begin{tabular}{|c|c|}
\hline TCAPP Priorities & Agencies Involved in TCAPP Process \\
\hline $\begin{array}{ll}\text { - } & \text { Energy efficiency in Diesel } \\
\text { truck cargo transportation } \\
\text { - } & \text { Direct use of natural gas } \\
\text { - } & \text { Renewable energy in rural } \\
& \text { electrification } \\
\text { - } & \text { Fuel cells } \\
\text { - } & \text { Electrical energy efficiency }\end{array}$ & $\begin{array}{ll}\text { - } & \text { Ministry of Mines and Energy (MME) } \\
\text { - } & \text { Research Center for Electrical Energy (CEPEL) } \\
\text { - } & \text { Nation Program for Fuel and Natural Gas Conservation } \\
& \text { (CONPET) } \\
\text { - } & \text { Petrobras } \\
\text { - } & \text { University of São Paulo } \\
\text { - } & \text { Ministry of Foreign Relations } \\
\text { - } & \text { National Council for Science and Technology } \\
\text { - } & \text { ELETROBRAS for Electric Energy (ANEEL) } \\
\text { - } & \text { Northeast Generation and Transmission Utility (CHESF) } \\
\text { - } & \text { PROCEL }\end{array}$ \\
\hline
\end{tabular}

\section{CHINA}

TCAPP work in China was initiated by the State Science and Technology Commission (SSTC) in February, 1998. Under the reorganization of China's government, the leadership for TCAPP was shifted in October 1998 to the Office of Climate Change Policy Coordination Committee, State Development Planning Commission.

The process used for preparation of the technology cooperation framework involved the following steps.

1. An interagency consultant team, consisting of experts from relevant ministries and commissions, was established to help select technology priorities and provide guidance for the development of the options in the framework. This team worked under the direction of SSTC and was coordinated by the Global Climate Change Institute of Tsinghua University, which was able to build on a series of previous analytic efforts it had been involved in, including the GEF/Asian Development Bank's ALGAS project, the U.S. Country Studies Program and Support for National Action Plans.

2. Research work on selecting technology priorities was carried out based on the results of domestic and international cooperative projects on GHG mitigation.

3. A scoping meeting was held in March, 1998. Nineteen technologies were considered. Four categories of criteria were applied, using an Analytical Hierarchy Process. The criteria categories were environmental benefits, economic development, conditions for technology transfer, and investment. Five technologies were selected. 


\begin{tabular}{|c|c|}
\hline Technology Priorities & Institutions Involved in TCAPP Process \\
\hline $\begin{array}{l}\text { Higher efficiency power } \\
\text { generation technology, } \\
\text { specifically Circulating } \\
\text { Fluidized Bed } \\
\text { Combustion } \\
\text { - High Efficiency Electric } \\
\text { Motor } \\
\text { - Advanced Industrial } \\
\text { Boilers } \\
\text { - Wind Power Generation } \\
\text { - Coal Bed Methane } \\
\text { Technologies }\end{array}$ & 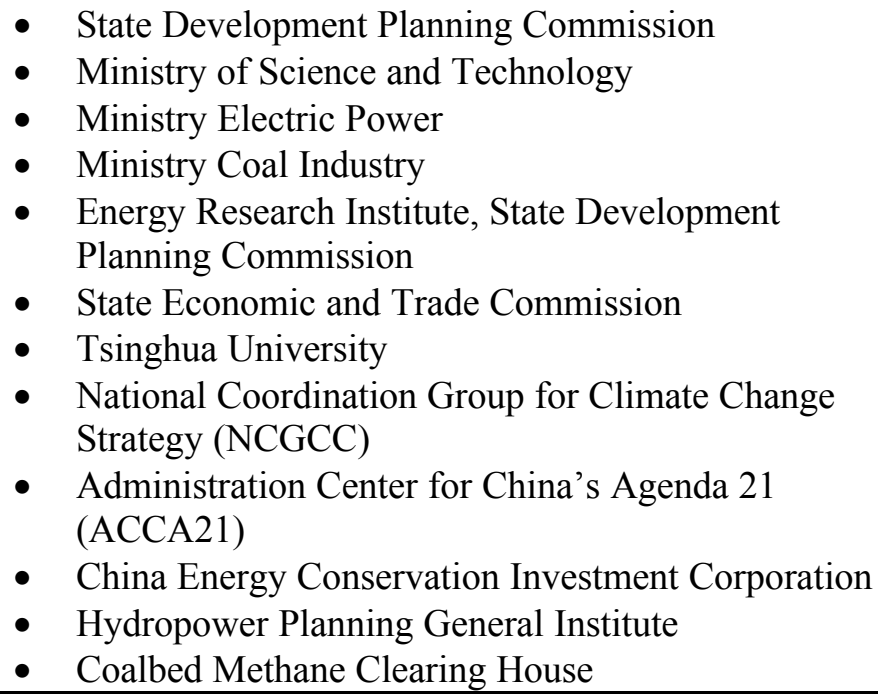 \\
\hline
\end{tabular}

4. Meetings held with Chinese representatives from the World Bank, UNDP, and JICA in March, 1998 to discuss opportunities for the technology cooperation framework to contribute to their ongoing programs. Additional research was conducted on market barriers and some key technology options to overcome these barriers were identified. The China team presented the TCAPP priorities at the Climate Technology Initiative meeting in Beijing, China in May, 1998.

5. The draft Technology Cooperation Framework was completed in August, 1998.

\section{KAZAKHSTAN}

Kazakhstan began work early in TCAPP. A team of five key personnel from the government Research Institute for Environment Monitoring and Climate (KazNIIMOSK) under the State Organization Kazhydromet, the Ministry of Energy, Industry and Trade (Ministry of Energy and Natural Resources at that time) was established for developing the framework in August, 1997. This team held a scoping meeting to select priorities in Almaty, on October 3, 1997.

The country team wrote a draft Technology Cooperation Framework and presented it at the November 1997 workshop in Golden, Colorado. The draft TCF was well received, and was chosen by TCAPP as the model for the program.

A temporary team of seven key personnel was established in July 1998, including experts from KazNIIMOSK, the joint-stock company "KEGOC", the energy designing institutes KazNIPIENERGOPROM and KazSELENERGOPROEKT. This team refined and narrowed the technology transfer framework developed in 1997 in accordance with the updated Energy Strategy, the Energy Saving Program, the Governmental Plan for 1990-2010 developed by Ministry of Ecology and Natural Resources and the Kyoto Protocol. A revised draft Technology Cooperation Framework was completed in September, 1998. 


\begin{tabular}{|c|c|}
\hline Technology Cooperation Priorities & Agencies Involved in TCAPP Process \\
\hline $\begin{array}{l}\text { Power Plant Carbon Efficiency } \\
\text { Program (Fuel-Switching, } \\
\text { Combined-Cycle Gas, and } \\
\text { Improved Heat Rate) } \\
\text { - Energy-Saving and District-Heating } \\
\text { Improvements } \\
\text { - Wind Power } \\
\text { - Small Hydro }\end{array}$ & $\begin{array}{ll}- & \text { Ministry of Ecology and Bioresources } \\
\text { (Agency for Hydrometeorology and Natural } \\
\text { Environment Monitoring) } \\
\text { - Ministry of Energy and Natural Resources } \\
\text { (NENR) } \\
\text { - Kazakh Research Institute for Climate and } \\
\text { Environmental Monitoring } \\
\text { - Kazakh Research and Design Institute for } \\
\text { Energy (KazNIPIENERGOPROM) } \\
\text { Kazakh Research and Design Institute for } \\
\text { Rural Energy (KazSELENERGOPROEKT) }\end{array}$ \\
\hline
\end{tabular}

\section{MEXICO}

The National Commission for Energy Conservation (CONAE) expressed interest in TCAPP in the fall of 1997 and sent a representative to the Golden workshop in November. At the workshop, the representative met with technical experts, donors and private sector organizations and developed a preliminary matrix of technology priorities, barriers, and proposed actions.

- CONAE conducted an internal follow-up meeting in March 1998, in which it affirmed its interest in playing a lead role in TCAPP. CONAE has not yet conducted an interagency consultative process, although it intends to do so in the near future. CONAE has selected priorities, using four criteria:Activities with known potential to create significant impacts in terms of fossil fuel consumption, economic impact, and private sector involvement

- Technologies in which Mexico has substantial experience

- Activities in which CONAE already plays a well-defined, lead role

- Activities that stand to gain significantly from multilateral donor support

CONAE selected three programs as priorities. The first two are national programs in the design stage, while the third is included with the intention of developing it into a large scale pilot program in Mexico City. The three priorities are:

- Nationwide expansion of efficient lighting in public buildings

- Nationwide expansion of steam generation and distribution systems

- Solar water heating pilot program

CONAE completed a draft Technology Cooperation Framework in early October 1998.

\section{PHILIPPINES}

The Philippines expressed interest in TCAPP in October of 1997 and sent a representative to the workshop in Golden, Colorado in November. The representative, who was from the Energy Resource Division of the Philippines National Oil Company (PNOC-ERD), developed a preliminary set of priorities.

A broader consultative effort began in March 1998, when the PNOC hosted a meeting in Manila to discuss the start-up of a TCAPP effort. The group, which included government agency, NGO 
and private sector representatives, agreed to proceed with TCAPP, and approved of the Philippines Department of Energy acting as the lead. The priority areas identified in November were extended to cover energy efficiency and other concerns of the energy sector.

In August 1998, the Philippine DOE and PNOC-ERD solicited the assistance of the Institute of Climate, Energy and Environment (ICEE) and the Manila Observatory (MO) in developing further the Technology Cooperation Framework. The project team reviewed the previous TCAPP documents and agreed on a common work plan. The work began with a review of past and present projects on energy efficiency and renewable energy. The team developed selection criteria and adopted priorities that had already been established in the following national programs:

- Renewable energy agenda of the Philippine Renewable Energy Network

- Energy Resources for the Alleviation of Poverty (ERAP) Program of DOE Action Plan on Climate Change (NAP)

- Asia-Least Cost Greenhouse Gas Abatement Project (ALGAS)

On August 21, a second consultation workshop was organized. Eighteen agencies representing the private, government, NGOs, and academe attended the consultation. The priorities were discussed - participants affirmed the priority programs as congruent with the identified priorities of the sector. Subsequent to this meeting, the technology cooperation priorities were refined based on this discussion. In approving the criteria and the priority programs, the participants agreed to submit the project concepts that were included in the Technology Cooperation Framework.

\begin{tabular}{|c|c|}
\hline Technology Priorities & Agencies Involved in TCAPP Process \\
\hline $\begin{array}{l}\text { Renewable Energy for Rural } \\
\text { - } \quad \text { Development } \\
\text { - } \quad \text { Photovoltaics } \\
\text { Energy Efficiency and Demand-Side } \\
\text { Management } \\
\text { - Utility Demand-Side } \\
\text { - Management } \\
\text { - } \quad \text { Apon-Utility Energy Efficiency } \\
\quad \text { Standards }\end{array}$ & $\begin{array}{ll}\text { - } & \text { Department of Energy } \\
\text { - } & \text { Philippine National Oil Company - Energy } \\
\text { - } & \text { Philippine Inter-Agency Committee on Climate } \\
& \text { Change (IACCC) } \\
\text { - } & \text { Department of Science and Technology } \\
\text { - } & \text { Department of Environment and Natural Resources } \\
\text { - Institute of Climate, Energy and Environment } \\
\text { - } \text { (ICEE) } \\
\text { - } \text { Panila Observatory (MO) } \\
\text { - Philippine Renewable Energy Network }\end{array}$ \\
\hline
\end{tabular}

The recent election in the Philippines of President Estrada has elevated the importance of sustainable rural development. In fact, the Assistant to the President on Poverty Alleviation has become involved with TCAPP and has discussed the program with President Estrada. The linkage of TCAPP to this important national priority is mentioned in the Technology Cooperation Framework, which was completed in early October and was highlighted in the presentation made by the President's assistant at the TCAPP Donor Meeting on October 9th. 


\section{OTHER COUNTRIES INTERESTED IN TCAPP}

Both India and Indonesia have expressed interest in TCAPP. Both countries sent representatives to the Golden workshop in November 1997. Indonesia conducted a scoping meeting in the fall of 1997. Unfortunately, political and economic difficulties have forced a suspension in TCAPP activities in these countries, at least for the time being. South Korea has also expressed interest in TCAPP and discussions are ongoing between the United States and the Korean government concerning their potential participation.

\section{The Next Phase of TCAPP}

Now that countries have identified the highest priority technologies for advancing clean energy investment, TCAPP is shifting emphasis to a new phase of activity to attract the private investment necessary for these technologies. This next phase includes two major thrusts:

- Attracting in-country and donor support to remove investment barriers

- Facilitating direct private investment for immediate market opportunities

\section{Removing the Legal and Institutional Barriers to Market Growth}

Removing legal and institutional barriers can be a difficult undertaking. TCAPP's approach is to build a substantial and concentrated effort by coupling in-country commitment and activities with international donor support. The TCAPP strategy begins with the priorities and proposed actions identified in the Technology Cooperation Framework. It then involves the following.

1. Assisting country teams in designing actions aimed at barrier removal. Country teams will determine which actions for addressing market barriers defined in their frameworks merit further development. This selection will be based on consultations with international and in-country businesses, international donors, government agencies in the country, and technical experts.

2. Developing Implementation Plans for Domestic Actions to Address the Market Barriers. Before preparing donor proposals, the country teams will need to first draft implementation plans that describe the steps that their government would like to follow to take action to address the market barriers. These implementation plans will define the specific steps necessary to remove this barrier and the role of donor agencies in supporting this action, as well as the availability of in-country resources to support the plan.

3. Preparing Proposals and Securing Donor Support for Selected Actions. TCAPP will assist country teams in preparing proposals to support these selected actions and in attempting to secure donor support for implementation. These proposals will build on the needs for donor support identified in the implementation plans.

\section{Identifying and Capturing Immediate Market Opportunities}

Market economies are strong enough in most TCAPP countries that there are areas where legal and institutional barriers do not stand in the way of energy efficiency and renewable energy projects. In these areas, TCAPP will capitalize on near term market opportunities by performing the following tasks.

1. Defining Immediate Business Investment Opportunities. TCAPP will assist the country teams in reviewing available market information and consult with the international businesses in the 
private sector network and with in-country businesses and investment organizations to identify the most promising opportunities for immediate investment in the clean energy technology priorities of the countries. The information will be compiled in a preliminary market assessments, which will include initial recommendations on actions for capturing investment in these targeted areas. The country teams will review the market information and then select the immediate investment opportunities that will be the focus of further work. The country teams will also develop initial recommendations on actions to be included in their investment programs to capture investment for these targeted opportunities.

2. Conduct Investment Planning Workshops. The country teams will hold investment planning workshops designed to initiate the development of business investment projects and to identify critical actions for facilitating further business investment in the targeted opportunities. Participants will include international businesses and investment organizations, international donors and technical experts, and in-country businesses, investment organizations, and government officials. TCAPP will establish teams, including in-country and international private sector representatives, country officials, and finance organizations to develop these investment plans.

3. Initiate Critical Actions Necessary to Foster Near-Term Business Investments. The investment workshops will identify key actions (e.g. financing support, business matchmaking, larger investment conferences, business capacity building, etc.) that the country teams, with some assistance from the TCAPP cooperators, can undertake to support near-term business deals. Some of the actions which will be considered include the following.

- Investment conferences in which potential business partners and financiers convene to put deals together and where other investment initiatives are discussed

- Disseminating information on the markets and potential projects to companies

- Recruiting private company participation and helping them find business partners

- Training to build local business capacity

- Identification of sources of financing and other sources of support (e.g. "Activities Implemented Jointly" pilot programs)

- Follow-up support, possibly including assistance in securing financing

\section{Next Steps for TCAPP}

\begin{tabular}{|l|l|}
\hline Expand Business Network & October - November \\
\hline Prepare Country Workplans and Establish Investment Teams & October - November \\
\hline Business and Donor Comments on Frameworks and Next Steps & September - November \\
\hline Preliminary Market Assessment & November - February \\
\hline Investment Program Planning Workshops & February - March, 1999 \\
\hline Design Investment Programs & March - June, 1999 \\
\hline Investment Programs begin & June - September, 1999 \\
\hline $\begin{array}{l}\text { Countries prepare proposals for donor support and secure domestic and } \\
\text { donor funding }\end{array}$ & January-September, 1999 \\
\hline
\end{tabular}




\section{Conclusion}

The Technology Cooperation Agreement Pilot Project (TCAPP) has demonstrated the value of a country driven process for establishing priorities for accelerating clean energy investment with active private business and international donor participation. The TCAPP process is also gaining recognition as an effective model for implementing technology cooperation as called for under Article 4.5 of the FCCC. TCAPP now faces the challenge of attracting the in-country, donor, and private sector resources necessary to help the countries realize their goals for accelerating implementation of their priority clean energy technologies. Meeting this challenge will require active participation of the international donor community and private sector in design and implementation of actions to address market barriers and mobilize private investment in these technologies. 
For more information on TCAPP in the following countries, contact:

\begin{tabular}{|c|c|}
\hline $\begin{array}{l}\text { Brazil } \\
\text { Jorge H. G. Lima } \\
\text { Head of Electronics Department } \\
\text { Centro De Pesquisas De Energia Eletrica } \\
\text { PO Box 2751 Rio de Janeiro, RJ 20001 970, Brazil } \\
\text { Tel: 55-21-598-2133 } \\
\text { Fax: 55-21-260-1340 or 6211 } \\
\text { E: jlima@fund.cepel.br }\end{array}$ & $\begin{array}{l}\text { Brazil } \\
\text { Eugenio Miguel Mancini Scheleder } \\
\text { Director de DNDE } \\
\text { Ministerio de Minas E Energia, Secretaria de Energia } \\
\text { Departamento Nacional de Desenvolvimento Energetico } \\
\text { Bloco U St. } 513 \\
\text { Brasilia - DF - CEP 70085-900, Brazil } \\
\text { Tel: (55-61) 321-2032 or 319-5012 Fax: (55 61) 224-1973 } \\
\text { Email: mancini@mme.gov.br }\end{array}$ \\
\hline $\begin{array}{l}\text { China } \\
\text { Ms. Li Liyan } \\
\text { Section Chief } \\
\text { Office to Climate Change Policy Coordination Committee } \\
\text { State Development Planning Commission } \\
\text { No. 38, S. Yuetan Street } \\
\text { Beijing 100824, P.R. China } \\
\text { tel: (8610)68576760 Fax: (8610) } 68576760 \\
\text { Email: emdspc@moon.bjnet.edu.cn } \\
\end{array}$ & $\begin{array}{l}\text { China } \\
\text { Mr. Wei Zhihong } \\
\text { Executing Director } \\
\text { Global Climate Change Institute } \\
\text { Tsinghua University, China } \\
\text { Tel: 86-10-6278-4828 } \\
\text { Fax: 86-10-6277-1150 } \\
\text { Email: zhihong@mail.inet.tsinghua.edu.cn }\end{array}$ \\
\hline $\begin{array}{l}\text { China } \\
\text { Mr. Lu Xuedu } \\
\text { Director, Division of Ecology and Environment } \\
\text { Dept. of Science and Technology for Social Development } \\
\text { State Science and Technology Commission } \\
\text { Beijing, China } \\
\text { Tel: } 86-10-68514054 \text { Fax: 86-10-68512163 }\end{array}$ & $\begin{array}{l}\text { Kazakhstan } \\
\text { Ms. Olga Pilifosova } \\
\text { Kazakh Research Institute for Environment } \\
\text { Monitoring and Climate (KazNIIMOSK) } \\
\text { Almaty, Kazakhstan } \\
\text { Tel: +7 3272 } 542527 \\
\text { Fax: +7 3272 } 542285 \\
\text { Email: pilifo@kniimosk.almaty.kz } \\
\end{array}$ \\
\hline $\begin{array}{l}\text { Kazakhstan } \\
\text { Sergey Katyshev } \\
\text { Head of Strategy Planning Department } \\
\text { KEGOC, Ministry of Energy, Industry and Trade } \\
\text { Shevchenko } 162 \text { "kv" } \\
\text { KEGOC, Ministry of Energy, Industry and Trade } \\
\text { Almaty, Kazakhstan } \\
\text { Tel: (++7) 3272682730 Fax: (++7) } 3272501198 \\
\text { Email: katyshev@kegoc.kz }\end{array}$ & $\begin{array}{l}\text { Mexico } \\
\text { Ubaldo Inclan Gallardo } \\
\text { Director of Planning and Environment } \\
\text { National Commission for Energy Conservation (CONAE) } \\
\text { Insurgentes Sur 890, 2nd Floor, Col. Del Valle, 03100 } \\
\text { MEXICO, D.F. } \\
\text { Tele: (525) 4486000 EXT. } 2068 \\
\text { Fax: (525) 4486228 } \\
\text { Email: conaepla@rtn.net.mx }\end{array}$ \\
\hline $\begin{array}{l}\text { Philippines } \\
\text { Donna Gasgonia } \\
\text { Presidential Assistant } \\
\text { Poverty Alleviation, NGO \& PO } \\
\text { Rm 1-B, New Executive Bldg., Malacanang } \\
\text { Manila, Philippines } \\
\text { Tel: (632) 734-5924 } \\
\text { Fax: (632) 735-6083 } \\
\text { Email: fpedzg@info.com.ph }\end{array}$ & $\begin{array}{l}\text { Philippines } \\
\text { Reuben Quejas } \\
\text { Department of Energy } \\
\text { PNPC Complex } \\
\text { Merritt Rd. } \\
\text { Fort Bonifacio } \\
\text { Metro Manila, Philippines } \\
\text { telefax:632-818-8614 } \\
\text { Email: rquejas@doe.gov.ph or ncedoe@doe.gov.ph }\end{array}$ \\
\hline
\end{tabular}

\section{For more information on the overall TCAPP effort, contact:}

\section{Mr. Jeff Seabright}

Director, Office of Energy, Environment and Technology, USAID

Phone: 202-712-4370 Fax: 216-3174

E-mail: jseabright@usaid.gov

\section{Mr. Ron Benioff}

Energy and Environment Team Leader

National Renewable Energy Laboratory

Phone: 303-384-7504 Fax: 384-7411

E-mail: ron_benioff@nrel.gov

\section{Mr. Paul Schwengels}

Program Manager, Climate Policy and Prog. Div. USEPA

Phone: 202-260-1192 Fax: 260-6405

E-mail: schwengels.paul@epa.gov

\section{Mr. Pat Keegan}

Climate Change Project Leader

National Renewable Energy Laboratory

Phone: 303-384-7472 Fax: 384-7419

E-mail: pat_keegan@nrel.gov
Mr. Christopher Bordeaux

Project Manager, USIJI and USCSP USDOE

Phone: 202-586-3070 Fax: 586-3485

E-mail: chrisopher.bordeaux@ee.doe.gov

Ms. Lisa Jacobson

Director, International Programs

Business Council for Sustainable Energy

Phone: 202-785-0507 Fax: 785-0514

E-mail: ljacobson@bcse.org 